\title{
SHAPES OF JAVANESE KERIS AS A SYMBOLIC SIGN: TRANSFORMATION TOWARD THE ISLAMIC PERIOD
}

\author{
Widodo Aribowo, Andrik Purwasito, and Titis Srimuda Pitana \\ Cultural Studies Program, Sebelas Maret University of Surakarta \\ Email: aribowo@hotmail.com
}

\section{Abstract}

In articulating the visual elements of Keris we will find the concept of symbols, each of which corresponds to the typology of signs. The relationships among the trichotomy signs associated with the codes represent the horizon of the Javanese society regarding the Keris culture. All the Keris signs establish the abstracts relationship model that never has any function before being associated with the code. Principally, people who become the message recipient can perform decoding act by associating the signs with certain conventions. The expression articulation through the Keris elements is a symbol in the typology of signs. The Javanese society's response or appreciation concerning the invented conventions needs to be investigated to conversely understand the system of signs production. The word kris, as an example, is semiotically classified into other words; keris, dhuhung, dhuwung, curiga, wangkingan, duwung, curiga, and katga, all of which refers to the same sign, which is the tipped stabbing weapons and covered in scabbard. This study found the cultural event of the ideological masking which represents certain period i.e. the deconstructive meanings on the luk of keris (kemba and rengkol) illustrated the ideological transformation from Hinduism to Islamic era.

Dalam mengartikulasikan unsur visual Keris kita dihadapkan dengan konsep simbol, di mana setiap simbol sesuai dengan tipologi tanda-tanda. Hubungan antara trikotomi tanda-tanda yang terkait dengan kode mewakili cakrawala masyarakat Jawa tentang budaya Keris. Semua tanda-tanda Keris membangun hubungan abstrak model yang tidak akan pernah memiliki fungsi apapun

el Harakah Jurnal Budaya Islam Vol. 19 No.2 Tahun 2017 
sebelum dikaitkan dengan kode. Pada prinsipnya orang yang menjadi sasaran penyampaian pesan bisa melakukan decoding dengan cara mengaitkan tandatanda pada keris dengan konvensi-konvensi tertentu. Artikulasi ekspresi melalui unsur-unsur dalam Keris memanfaatkan simbol-simbol dalam tipologi tanda. Respons maupun apresiasi orang Jawa terkait dengan konvensi-konvensi yang telah diciptakan para leluhur perlu diketahui untuk melihat secara terbalik dalam sistem produksi tanda. Pemaknaan kata kris misalnya, secara Semiotis dapat diklasifikasikan berdasarkan beberapa kata referensial di antaranya keris, dhuhung, dhuwung, curiga, wangkingan, duwung, curiga, dan katga semua menunjukkan petanda yang sama yaitu senjata tikam yang berhulu dan berwarangka. Penelitian ini menemukan terjadinya peristiwa budaya berupa penopengan (masking) ideologi yang mewakili zaman tertentu, misalnya dekonstruksi pemaknaan bentuk luk keris (kemba dan rengkol) menggambarkan transformasi ideologi zaman Hindhu menuju zaman Islam.

Keywords: convention; Keris; semiotics; sign

\section{Introduction}

Keris or a traditional Javanese dagger has become the world nominated heritage of UNESCO in November 25, 2005. Indonesians are supposed to provide as much as possible all the information regarding Keris to the world societies. The question is why Keris can exist since 700's. Keris from time to time had never changed significantly; in fact, they were just developed in other variants. Approximately, there are 800 dhapur Keris found throughout the archipelago.

Dhapur Keris is a technical term to name various types of Keris, seen from the ricikan (blade) on a Keris that can be respectively seen on the numbers of each curvaceous-shaped (Harsrinuksmo, 2008: 136). Its various names characteristically based on the dhapur which indicate the need and high attention of the community on the existence of Keris itself. In other words, Keris is part of Indonesian's life, especially the Javanese society. The deployment of Keris covered the area formerly known as the archipelago, except Papua in which no Keris tradition is found (Jensen, 2007: 2).

Keris represents history, born by history, and created through history. Various historical stories and legends marked the birth and the involvement of Keris in the social, culture, politics, and economic context of Indonesia nation and the archipelago. The Javanese Keris has undergone a long journey proving the fact that Keris was born in Java, experienced a golden age in Java, 
and met its destruction in Java. Keris was first appeared in the land of Java. It is approximately introduced in $230 \mathrm{AD}$ as a means of a defense system of Medangkamulan kingdom which geographically located in the complex of Mount Lawu in the reign of the Buddhist Mahadeva (Arifin, 2006: 4). Although this information requires more in-depth study, the reference as found in several inscriptions and ancient literatures indicates that the culture of Keris is subsequently very old.

The golden age of Keris was in Java. People believe that the peak of Keris creation was at Sultan Agung period (1613-1645), in which Keris was manufactured in this period (known as tangguh or tough), its beauty is supported by the finest materials, and contained powerful magical sense (interview with Basuki Teguh Yuwono, March 6, 2016). Conversely, Keris' deterioration was also in Java. Many of them have been sold in street stalls at reasonable prices. Moreover, there are frauds in Keris transactions which is based on the economic interests. There certainly is a knowledge gap between the intermediaries (known as a broker or pengempit) and buyers who actually wish to own the Keris as an achievement of their maturity in individual, social, and spiritual factors. Eventhough this unfortunate situation can be, literally, "saved" by the UNESCO award, various motives of fraud in Keris transactions remain a great challenge until today.

The causes of Keris' existence in the resurgence of cultural flow certainly deserve critical view. The shapes (dhapur), pamor and accessories of Keris such as the hilt, mendhak, selut, and pendhok have never changed over time. Among so many ancient Keris, some of them still exist now, i.e. Keris dhapur Sangkelat first manufactured at the reign of Majapahit. Keris dhapur Anggrek which was first manufactured at the time of Kahuripan has been well-maintained through generations of each Javanese rulers. This creates a sense that several variants of Keris Anggrek come into existence. Similarly, Keris dhapur Jalak is renowned for its many variant (no less than 21 variants) compared to other dhapur.

Knowing little insight of Keris and its attributes including the styles, we will easily find out how the Keris had been distinctively interpreted throughout the ages. According to Maisey (2013:2) the classified history of Keris divided into three phases: a) pre-Islamic, b) the Islamic, and c) post-Islamic periods. Keris, in the pre-Islamic and the previous period (known for zaman kabudan until the collapse of the Majapahit reign), had different function compared to the Islamic period. The conspicuous difference of both periods is shown in the pre-Islamic period; Keris functioned as a means of worship and weapons. 
The works of Keris in the Islamic period mainly functioned as the media of communications to deliver advice (piwulang kautaman). In other words, Keris as an artifact remains the same in shapes, although each of them may reflect the different function and meaning.

\section{Methods}

This study applies a semiotic analysis to reveal the meaning reflected from the text. Through semiotic analysis, a large number of sign systems manifest in Keris can comprehensively reveal the equivalences and visual characteristics of the features. The data collection technique employs documentation. The information is mainly obtained from direct observation to informants (the expert of Keris) concerning the philosophy, the shapes, and other types of Keris, both as a personal belonging of inheritance and as a property documentation of Kraton (primary data). The resource person is Basuki Teguh Yuwono, 40 years old, a Master (Empu) of keris living in Wonosari village, district of Gondangrejo, Karanganyar Regency. In addition, several documents such as textbooks, journals of relevant studies on Keris (secondary data) highly contribute to the analysis on the objects of discussion in this paper.

\section{The Trichotomy of Sign}

Keris, both as a means of worship and a means of expression, has the elements of sign which require further study. The science of signs, the interpretive semiotics in particular, directs the researcher to interpret and understand the code (decoding) behind these signs (Piliang, 2012: 313). Additionally, Semiotic method works on two levels of analysis, namely the individually sign and a group or combination of sign. The individually sign is specified according to the trichotomy of sign, signified, and signifier in Semiology (Martinet, 2010: 64).

Signifier is a kind of image of sound or visual representation while the signified is the explanatory concept. Signifier and signified concern the idea of a relationship in which a sign interrelated between the signifier and signified is acceptable. This assumption brought the principle that the sign concerns the expressive element (not a physical entity) and is a cornerstone meeting of various independent elements (Eco, 2009: 70).

The elaborated terms shall be used as a point of departure to create map of signs individually on Keris and the meanings are interpreted contextually. Another important thing that should be emphasized is that the articulation of expression through elements of the Keris is a symbol in the typology of 
signs. Symbol in the Semiotics is the arbitrary nature of the relationship between signifier and the signified. The relationship among the trichotomy of signs will then be presented and associated with the codes representing the horizon of the Javanese society and are characteristically conventional. The composition of the related codes of sign reflects something or represents particular ideology. By this method, the puzzle of a short overview of Keris shall be revealed. Considering the given scope, this article limits its discussions on the sign system related to the shapes of Keris.

\section{The Signifier and Signified on the Terms of Keris}

The naming of Keris can be found in the inscription of Karangtengah, indicated in written number of the year $824 \mathrm{AD}$. The term 'patuk kres i' is written on that inscription which is reinforced by the testimony on the inscription of Poh (907) mentioning the word kres as part of the process of ritual offerings (Arifin 2006: 13). The word kris further evolved into the word 'Keris'. Another term for Keris or dagger in the pre-Islamic period is dhuhung that is still a widely used term in Bali. Balinese proverbs dhuhung manjing warangka and warangka manjing dhuhung imply that the position of Keris as the top part and warangka as the bottom part. The union between these two elements described in Panjingan Keris reflects a dichotomous unity, i.e., the union between Gusti and Kawula, the heavens and the earth, day and night, and so on. The word dhuhung itself is a variant (lira-liru) and its meaning equals to the word luhung and luhur in Javanese language. The next word dhuhung in the Javanese language varies with the word dhuwung. Thus, the word dhuwung introduced in Javanese is currently a term given to the dagger, which is a continuation of the previous period. Another name for Keris is katga which is rarely used.

Other names that refer to Keris appeared more recently such as curiga, wangkingan, and duwung, are conceptually different from "dhuwung" 'to entrust' with additional character ' $h$ ' in the middle of the word to refer to the connotative word 'regret' (keduwung) that always comes at last, literally after the event or deed, like the traditional common use of Keris that is always put at the back of a man. The word kris, keris, dhuhung, dhuwung, wangkingan, duwung, curiga, and katga, all of which refers to the same signified, which is the tipped stabbing weapons and have warangka in them (Harsrinuksmo, 2008: 233; Jensen, 2007: 12; Arifin 2006: vii). In addition to the initial name of Keris, other words is a parable of the elaborated connotations of the use, i.e.

el Harakah Jurnal Budaya Islam Vol. 19 No.2 Tahun 2017 
the so-called curiga because it was worn at the front of a person representing a symbol of the attitude to always be in vigilant; worn on the back then called wangkingan or duwung. The word dhuwung was used for symbol in binary opposition as opposed to warangka in which the dhuwung is at the top while warangka at the bottom.

\section{Connotation on the Shapes of the Javanese Keris}

Various signifiers are in paradigmatic relations. The first layer functions as a medium of connotations represented among the shapes of Keris. Visual elements regarding the shapes of the Keris are also a text that has similar expressive value as the written text (Bondanella, 1997: 55). In the written text, the sign relations reflect both the paradigmatic and syntagmatic nature, and the visual signs represent both paradigmatic and combination relation.

The shapes of Keris essentially nuanced with a post-structural phenomenon. If the binary opposition of structuralism of the right is wrong, then this case does not prevail to Keris. There are roughly two forms of Keris: first, Keris in perpendicular-shaped in the Javanese language is in paired with the word leres and bener which mean 'right' (Prawiroatmojo, 1985: 304). Second, Keris in curvaceous-shaped or wavy (luk). Thus, the binary opposition of leres or straight is not wrong or lepat but mawa luk.

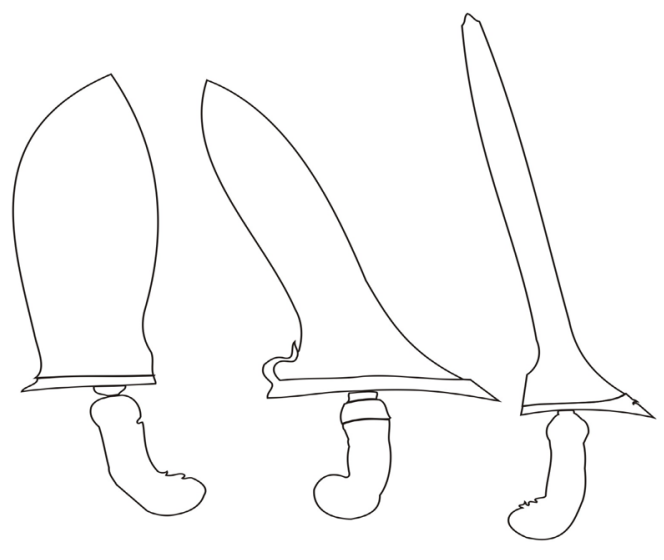

Figure 1. Perpendicular-shaped (unscalled image)

Keris in perpendicular-shaped according to Maisey (2013: 4), if it is drawn the imaginary line, it will form a triangle. There is a triangle that shaped symmetrical but mostly asymmetrical. The established wider triangle 
line at the bottom (called a sor-soran) and tapering to the top (called pucuk or panetes) with normal height between 33 and $38 \mathrm{~cm}$. The triangular blade of Keris varies in shape, there is a relatively wide circular (buweng), wide and slim tapered (ngrangin). If it is seen from the waist (wadidang), there is Keris which is wide at the bottom but is getting smaller and tapered at the tip. This shape is called indentation which is unlike the human waist. Most of Keris is the waist shaped, though some may be triangle, but all of them seem to remain curvaceous-shaped on the bottom up to the tip. The first shape - the un-waist one is called mucuk bung.

The sharpened part of the Javanese Keris comprises four types: mbuntut tuma (the tail of lice), anggabah kopong (the empty rice grains), ngudup gambir (Gambir flowers), and nyujen (skewers). The tip of Keris mbuntut tuma and ngudup gambir signify that a blade of Keris is three-dimensional (the thicker blade) and the other two are two-dimensional. The blade of three-dimensional shaped triangle if it is viewed from its side, front, or back. Unlike other sharp weapons such as sword, both sides of Keris is straight and curvaceous-shaped, which is the sharpest side.

Symmetrical triangle is commonly formed by other parts of Keris called ganja (the bottom side of Keris), especially ganja with sepang motive. In addition to ganja Sepang, all Keris are asymmetrical in which one side is front part or the face (wadana). Both symmetrical and asymmetrical Keris-including Keris in curvaceous-shaped-if it is laid on a standing position and compared with the peksi (the bottom of Keris resembles a stick, a large part goes into the top), such position does not standing but slightly front leaning (toward the connotations as face). This position is a slightly leaning, traditionally called condhong leleh. There is only one front leaning than other Keris, namely dhapur mayat. Thus, Keris in curvaceous-shaped manifests secondary signs, namely:
a. triangular shaped
b. two and three-dimensional of triangular
c. wide-round, wide-tapered and slim shaped of triangular
d. tapered at the top
e. triangle that has and do not have a waist at the bottom
f. the tapered part is not one type, instead four types
g. the symmetrical triangle and mostly asymmetrical
h. there are the front sides (face) the back sides
i. both the front and the back are the sharpest side
j. leaning towards the front (face) 
Keris in curvaceous-shaped (keluk) is the one which both sides are sharp in wavy-shaped, to which the numbers of the curves always remain in the odd number (luk 3, luk 5, 7, 9, etc.) (Harsrinuksmo, 2008: 262). Maximum number of luk on certain tough Keris was 11, but after the end of Majapahit kingdom, the number of luk varied into 13, 17, 19, 31, etc. Just like Keris in perpendicular-shaped, Keris in curvaceous-shaped forms a triangle, wider at the bottom and taper to the top.

Taking a closer look at the wide blade, there is Keris which is relatively wide and curvaceous-shaped (birawa), some are slim, and others are moderate. Based on the width and number of curvaceous-shaped, it generated a combination of Keris in both deep (rengkol), and shallow (kemba) curvaceous-shaped and moderate. Keris rengkol generally manufactured after the end of Majapahit era before the Islamic period, while the shallow Keris 'luk kemba' manufactured earlier. Keris luk rengkol, kemba, and the moderate led to a different imagery of Keris.

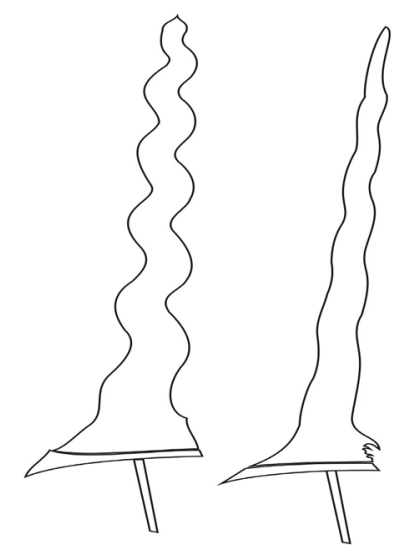

Figure 2. Curvaceous-shaped Keris. Left: deep curved or rengkol, right: shallow curved or kemba (unscalled image).

Keris in curvaceous-shaped may not always be even from the bottom to the top. There are some with curvaceous at the bottom and perpendicular at the top (dhapur bango dholog), curvaceous just at the middle (dhapur campur bawur), there are also perpendicular at the bottom and then curvaceous at the top (i.e. dhapur urubing dilah). Another combination resembling Keris in perpendicular-shaped both in terms of type of tips, the front, condhong leleh, but hardly found the Keris of mucuk bung curvaceous-shaped. 
In addition to reflect the secondary signs, as reflected from the perpendicular-shaped, Keris in curvaceous-shaped also characteristically matches with the following criteria:

a. sharp blades in wavy-shaped
b. always consisting of odd number of curves
c. a wide blade, slim, and moderate-shaped
d. have a deep, shallow, and moderate curvaceous-shaped

All of these signs establish the abstracts relationship of Saussurean model and shall never have any function before being associated with the code (Piliang, 2012: 24). In the scheme proposed by Shannon and Weaver, presentation of the symbols in informational resources is directed to produce a message that must be transmitted to the receptor (in Martinet, 2010: 11). Transmitters treat the message so as to create both the encoding-decoding signs in order to get to the destination. The code is a way of combining the signs that work within the social conventions to enable the message delivery from one person to another (Piliang, 2012: 16). Piliang (2012) further elaborated that according to Roland Barthes code is a game come across and interacted with signs or quotations that form the illusion of structure. Thus, there is a freedom in playing with signs or the existing visual elements.

The targeted people of a delivery message can perform an act of decoding by associating the signs with conventions. Traces of the social conventions concerning Keris spread out across many written and unwritten sources. The written sources, for example, can be traced from many books or texts discussing about Keris. The unwritten sources concern with the beliefs, histories, and the legendary stories transmitted orally across many people and mainly as traditionally transmitted among the Keris masters (empu) along with the developed and myths associated with it. Thus, on the basis of such accounts, shall reveal the following concerns.

1. That the triangle forming Keris in perpendicular-shaped is a picture of a mountain or a tree that manifest in itself the ancestral spirits. The origin of such Javanese belief was primarily in glorifying ancestral spirit. People believe that their ancestors literally did not die; they are just living in the spirit world, and live in large trees or in the mountains. Tree (tree of life) and the mountain as something that stands out above all are considered approaching a place where the supernatural power exist (Kartika, 2007: 23).

2. The original belief of Java had once developed at the time of Hindhuisme and Buddhism. The belief in the dwelling places of the ancestors slowly 
replaced by the gods that the people worshiped on the mountain. In India (as the origin of the belief bar) the gods lived on top of the Mount Mahameru, and in Bali (for example) the mountain is symbolized by Meru while in Java denoted with the mountains (Maisey, 2013: 5).

3. The symbolization of this mountain has further met with deconstruction at the Islamic period, where the mountain symbolized a visualization of Keris with the Mount of Tursina as described in joint with other parts namely kembang kacang (Arifin, 2006: 85).

4. The sharp blades of Keris symbolize the sharpness of thought and the human heart so that human can be a sensitive being in reading to the signs of nature.

5. The front face of Keris is a symbol that Keris is a personification of the stylized human in whatsoever so that it only appears as imagery. This personification has been unified with the front leaning position; this reflects an advice that in everyday life, human should always be submissive and respectful.

6. Condhong leleh describes the attitude angron akung (like a leave that tends to bend inside when separated from the stalk and exposed to heat). This attitude is a submissiveness that is specific to the Javanese trait who is supposed to always be in submission and respectful, not only to God but also to other humans (Harsrinuksmo, 2008: 9)

7. Keris in curvaceous-shaped in which the number of curves must always be odd number. An odd number means the picture of human life is always in the process of achieving. No man is perfect, nothing is fulfilled. If it is completed, it has finished. Human life should always be dynamic and have a willingness to go forward (Harsrinuksmo, 2008: 262).

8. The wide, slim, and moderate blades which lead to the deep and shallow curves represent the symbols for a dragon, snake, or fire. The shallow curve (kemba) is a symbol for Sanghyang Basuki (the god in a dragon manifestation) whose presence has always been believed by the community who embrace the Hinduism as a source of safety for a person and his or her family (interview with Basuki Teguh Yuwono, March 6, 2016). At the end of Majapahit period, Keris has been subtly deconstructed by the Wali 'trustees' that come along with the influence of Islam. Naga connoted as distress, and the figure of the dragon changed into a snake that internationally referred to the symbol of salvation. Instead the figure of a dragon interpreted as a distress should be avoided. It is institutionalized in the form of science iladuni or 
sawerduni to the calculation in determining the days of survivors to travel or go to a nice place in a metaphorical sense and the true meaning. The science so called sawerduni described as a nagadina that threaten human safety at the time they go into somewhere.

9. Keris luk kemba (superficial) is a metaphor of the dragon. This becomes a belief system in Hindhuism that the higher the degree of something (life force, the less motion. So, the god of the highest rank described was not moving at all. This belief is visible in the imagery of puppets purwa where the highest god Batara Guru portrayed his hands were steady. Likewise Shiva as the supreme deity has meaning suwung or empty. Instead luk rengkol symbolizing snake that has a lot of motion and requires a large force to move. Snake in the post-Hindhuism is the description of human behavior dynamics in living his life, had to move in order to stay alive (interview with Basuki Teguh Yuwono, March 6, 2016).

10. The curvaceous-shaped or luk in a Keris is also a symbol of the fire and is used specifically to describe the keris dhapur, i.e. urubing dilah (if it is in the palace) or damar murub (if it is outside the palace). Keris luk kemba symbolizes fire in the room (also reflects the controlled fire inside the human) that is not affected by weather such as wind and air temperature to be almost straight up. Conversely, the luk rengkol symbolizes the fire outdoors or dynamic flame as a symbol of human life. It can be seen that Keris along with the magical power that helps people in seeking for fortune usually manifested in the luk rengkol (interview with Basuki Teguh Yuwono, March 6, 2016)

\section{Historical Facts}

The above mentioned semiotic description is in line with historical facts about the coming relation of Islam influence. That kind of deconstructive meaning is estimated to occur at the end of Majapahit to Demak Bintoro period. Evidences of cultural practices as a result of the flourishing of Islam are realized in the artifacts of historical value as follows. First, in Islam there is a ban on depictions of living things, especially animals and humans realistically. Cultural practices in response to that ban appear in the elements of sandhangan (dress) keris:

a. The creation of the nunggak semi (sprouting plant) shaped of deder which is a stylized form of the human body by Sunan Bonang (Jensen, 2007: 2) 
b. The creation of the warangka shaped wulan tumanggal (crescent moon) or in Yogya is called warangka tanggalan as an adoption of the symbol in Islam

Second, the creation of new shapes in keris blades is different from previous i.e.:

a. greneng (thorn) on the back side of keris that in the past formed the letter "om" (Maisey, 2013: 28) to form the Arabic letter 'syin',

b. application of pamor tambal (pamor which is later attached to the blade) sayings the Islamic utterance such as syahadah,

c. application of Arabic letters in tinatah motif previously in the form of animals (elephants, lions, and dragons), lung-lungan (tendrils), and lotus flowers that connotes worship in Hindhuism,

d. the ganja can be found also in wulan tumanggal shape.

Third, there is a new meaning practice of keris function as a marker for maturity where in procession of circumcision a teenage moslem get keris (the smaller one) called seking (Yuwono, interview 22 July 2017). Seking type in the past was a part of war device of Sunan Giri's troops when fight the attacks of Kadipaten Surabaya, as the following quote:

kalih atus winatawis | whose number is two hundreds

samya asikêp sanjata | ready with all their weapons

nyothe sêking (ng)gendhong towok | seking on back waist like so with small spear

panganggene sarwa pêthak | dressed in white

wus samya masuk Islam | all have embraced Islam

sabilollah unènipun | the unit is called sabilollah

ing wuri sang Endrasena | lined up behind Senapati Endrasena

(Sastra Lestari Foundation, 1986: 33)

Meanwhile, the keris community knows a master named Empu Modin (real name Bekeljati). He comes from Tuban who is within the territory of the kingdom of Majapahit. Bekeljati is a muazin. The word muazin gradually changed into modin (Harsrinuksmo, 2008: 295). 


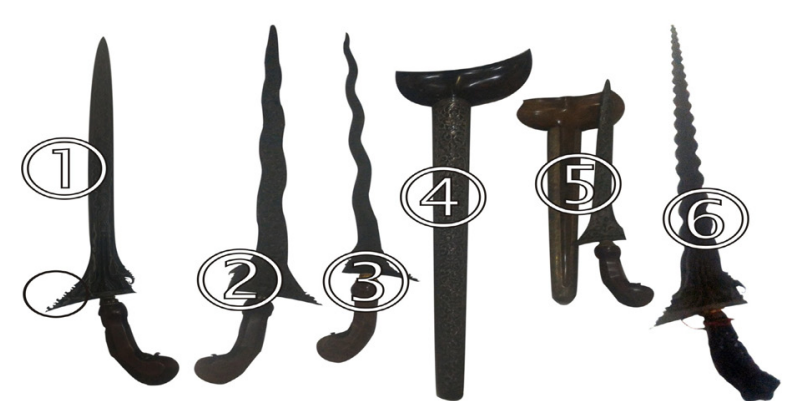

Figure 3. Artifacts that mark the relation of Islamic civilization and Javanese keris

Description:

1. this greneng part forms Arabic letter 'syin' (Courtesy of Brojobuwono Museum)

2. Hindhuism keris with its shallow curves (kemba) (Courtesy of Brojobuwono Museum)

3. keris from Islamic Mataram era with its deep curves (rengkol) (Courtesy of Brojobuwono Museum)

4. keris sheath wulan tumanggal shaped (Courtesy of Brojobuwono Museum)

5. seking type of keris (Courtesy of Brojobuwono Museum)

6. a Cirebon Sultanate keris with its 39 curves (Courtesy of Fadli Zon Library)

\section{Conclusion}

In articulating the visual elements of Keris, we found the concept of symbols, each of which corresponds to the typology of signs. The relationships among the trichotomy of signs associated with the codes represent the horizon of the Javanese society regarding the culture of Keris. All the signs of Keris establish the abstracts relationship of Saussurean model that shall never have any function before being associated with the code.

There are roughly two forms of Keris, the perpendicular-shaped and the Keris in curvaceous-shaped or wavy $(l u k)$. Most of Keris is in waist shaped, though some may be in triangle, but all of them seem to remain curvaceousshaped on the bottom up to the tip. Keris along with its development and myths associated with itself. The triangle that forms Keris in perpendicularshaped is a picture of a mountain or a tree that manifest in itself the ancestral spirits. The sharp blades of a Keris symbolize the sharpness of thought and the human heart so that human can be a sensitive being in reading to the signs of nature. The front face of Keris is a symbol that Keris is a personification of 
human body as an imagery. Condhong leleh describes the submissive attitude angron akung. The curvaceous-shaped or 'luk' in a Keris is also a symbol of the fire and is used specifically to describe the keris dhapur, i.e. urubing dilah (if it is in the palace) or damar murub (if it is outside the palace). Keris luk kemba symbolizes fire in the room (also reflects the controlled fire inside the human), and many other as has been elaborated in the discussion.

Last but not least, the Javanese conventions that have been built on shapes of Keris by the ancestors have to be understood to unmask the signs production system. Semiotic signs are in line with the historical facts found in the research.

\section{References}

Arifin, MT. 2006. Keris Jawa Bilah, Latar Sejarah, Hingga Pasar. Jakarta: Hajied Pustaka.

Bondanella, Peter.1997. Umberto Eco and the Open Text. Cambridge: Cambridge University Press.

Eco, Umberto. 2009. Teori Semiotika. Yogyakarta: Kreasi Wacana.

Harsrinuksmo, Bambang. 2008. Ensiklopedi Keris. Jakarta: Gramedia Pustaka Utama.

Jensen, Karsten Sejr. 2007. "Central Javanese Krisses”. Krisdisk Chapter 5. Unpublished.

Kartika, Dharsono Sony. 2007. Budaya Nusantara: Kajian Konsep Mandala dan Konsep Triloka/Buana Terhadap Pohon Hikayat pada Batik Klasik. Bandung: Rekayasa Sains.

Maisey, A.G. 2013. An Interpretation of the Pre-Islamic Javanese Keris. Arms Cavalcade. May, 2013. ISSN 1325-779X

Martinet, Jeanne. 2010. Semiologi Kajian Teori Tanda Saussuran. Yogyakarta: Jalasutra.

Piliang, Yasraf Amir. 2012. Semiotika dan Hipersemiotika. Bandung: Matahari. Prawiroatmojo, S. 1985. Bausastra Jawa - Indonesia. Jakarta: PT Gunung Agung. Sastra Lestari Foundation. 1986. Manuscript \#761. Centhini Kamajaya. Vol. $01 / 1$. 